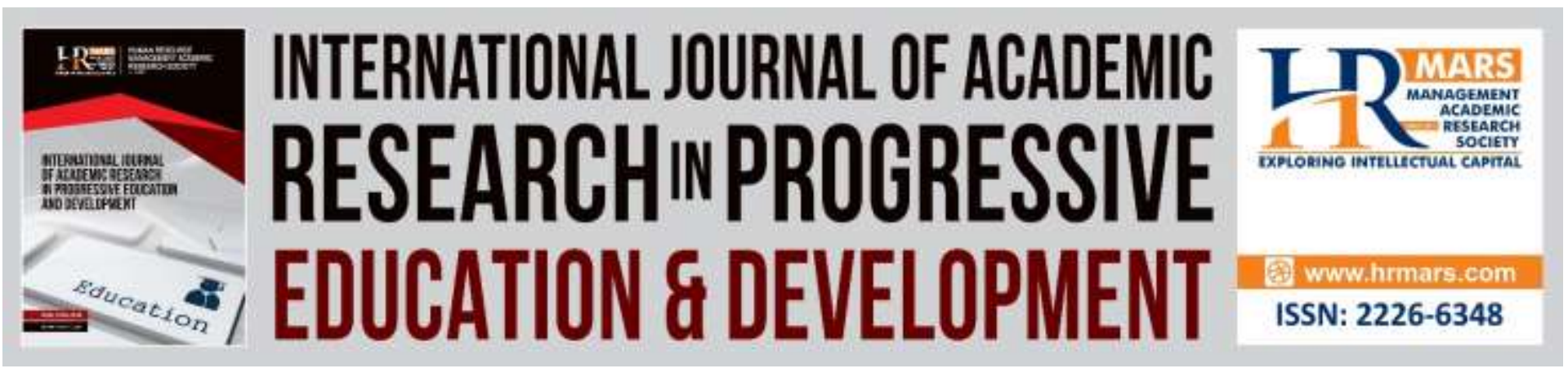

\title{
Examining Professional Learning Communities in National-Type Chinese Primary Schools in Perak, Malaysia
}

\author{
Tai Mei Kin, Omar Abdull Kareem, Khalip bin Musa
}

To Link this Article: http://dx.doi.org/10.6007/IJARPED/v8-i2/6121

DOI: 10.6007/IJARPED/v8-i2/6121

Received: 12 Jan 2019, Revised: 25 Feb 2019, Accepted: 10 March 2019

Published Online: 29 March 2019

In-Text Citation:(Kin, Kareem, \& Musa, 2019)

To Cite this Article: Kin, T. M., Kareem, O. A., \& Musa, K. bin. (2019). Examining Professional Learning Communities in National-Type Chinese Primary Schools in Perak, Malaysia. International Journal of Academic Research in Progressive Education and Development, 8(2), 418-438.

Copyright: (C) 2019 The Author(s)

Published by Human Resource Management Academic Research Society (www.hrmars.com)

This article is published under the Creative Commons Attribution (CC BY 4.0) license. Anyone may reproduce, distribute, translate and create derivative works of this article (for both commercial and non-commercial purposes), subject to full attribution to the original publication and authors. The full terms of this license may be seen

at: http://creativecommons.org/licences/by/4.0/legalcode

Vol. 8(2) 2019, Pg. 418 - 438

http://hrmars.com/index.php/pages/detail/IJARPED

JOURNAL HOMEPAGE

Full Terms \& Conditions of access and use can be found at http://hrmars.com/index.php/pages/detail/publication-ethics 


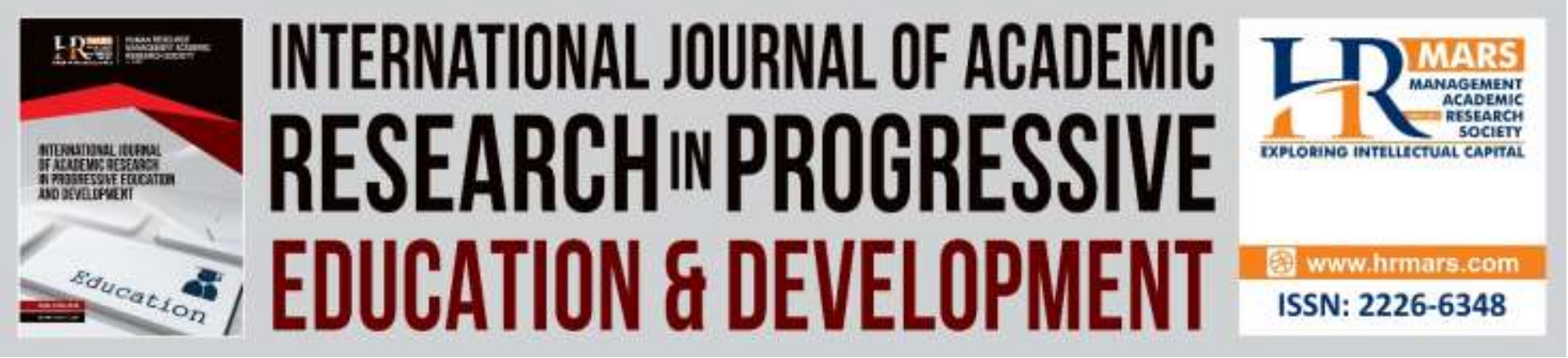

\title{
Examining Professional Learning Communities in National-Type Chinese Primary Schools in Perak, Malaysia
}

\author{
Tai Mei Kin ${ }^{1}$, Omar Abdull Kareem², Khalip bin Musa ${ }^{3}$ \\ 1, 2, 3 Department of Educational Management, Faculty of Management and Economics \\ Sultan Idris Education University, 35900 Tanjong Malim, Perak Darul Ridzuan, Malaysia \\ Email: taimeikin@fpe.upsi.my
}

\begin{abstract}
Professional learning communities contribute greatly to teacher professionalization and school improvement. The purpose of the study was to examine the patterns of professional learning communities (PLCS) in the National-type Chinese Primary Schools (NCPSs) in Perak, Malaysia. A total of 630 head teachers, senior assistants and teachers completed the survey with usable data. The result revealed that, i) the NCPSs achieved the level of Quite Good in PLCs, in its two dimensions of Organization Factor and Non-Organizational Factor as well as its eight sub-dimensions; ii) the NCPSs achieved a higher mean score in Organization Factor than Non-Organizational Factor of PLCs and the difference was significant; iii) among all the sub-dimensions of PLCs, the NCPSs achieved the highest mean score in Head Teacher's Commitment and Support; iv) among all the subdimensions of PLCs, the NCPSs achieved the lowest mean score in External Support System. The results indicated that the NCPSs in Perak needed to improve the implementation of PCLs so as to be effective in addressing school reforms.
\end{abstract}

Keywords: Professional Learning Communities, Shared Norms and Vision, Head Teacher's Commitment and Support, Structural Support, Colleague Understanding and Trust, Collaboration, Reflective Dialogue, Collective Inquiry, External Support System.

\section{Introduction}

A substantial body of research has demonstrated that teacher quality is the most determinant factor of student outcomes (Jensen, 2012; Hairon, 2016; Tai et al., 2018; Wang, 2015) and research conducted in the world's most improved school systems found that high-performing teachers can improve student achievement by up to $50 \%$ over a three-year period (Ministry of Education Malaysia, 2013). Complex global dynamics and the pace of contemporary change have constantly challenged the role of teachers, making teacher tasks increasingly complex and requiring a major shift in skill sets and knowledge. Therefore, there has been an increased demand upon teacher 
INTERNATIONAL JOURNAL OF ACADEMIC RESEARCH IN PROGRESSIVE EDUCATION AND DEVELOPMENT

Vol. 8, No. 2, 2019, E-ISSN: 2226-6348 @ 2019 HRMARS

professional development across the world educational systems in terms of expanding teacher capacity with new competencies aligned to new learning standards and expected educational goals.

There is a general agreement in educational literature that teacher professional learning that are time-limited, short-term, one-off and de-contextualized do not focus on the individual needs of the teachers, and do not provide sufficient follow-up, being disconnected from teachers' previous learning; these have been found to lack relevancy and effectiveness in comparison with those that are long term, situated, practice-based, inquiry-oriented, non-linear, emergent and transformative (Desimone, 2009; Keay, Carse \& Jess, 2019). Indeed, with the growing needs for educational excellence, the most effective approaches for teacher professional learning remain complex and dynamic; instead of supporting the acquisition of knowledge and skills, the current paradigm shift in teacher professional development is focusing on how to help teachers to play an active role in collectively constructing knowledge on teaching and learning that can create sustainable and lasting impact on teachers' learning and teaching capacities (Hairon, 2016; Tai \& Omar, 2019).

Professional learning communities (PLCs) have been found to be one of the more viable systemic and comprehensive approaches with relevant characteristics that engage teachers in meaningful and impactful professional learning (Hipp \& Huffman, 2010; Olivier \& Hipp, 2016; Qiao, Yu, Zhang, 2018); teachers in PLCs act as their own agents, proactively taking initiatives to construct knowledge collectively through shared vision and values, within a construct of collective responsibility, collaboration and professional learning practices. On this note, PLCs are perceived to be a significant and powerful staff development approach, with the potential to reframe teaching and learning practices, and effectively provide diverse learning experiences contingent to the needs of the students (Harris et al., 2018; Olivier and Huffman, 2016; Qiao et al., 2018; Vangrieken et al., 2017).

The Ministry of Education (MOE) of Malaysia started to implement PLCs in the schools from the year 2011. The concept of PLCs was embraced in 1,548 schools as part of the schools' CPD strategy to improve teachers' professionalism (MOE, 2015). Following this, PLC was accredited in the Malaysia Education Blueprint 2013-2025 as one of the powerful approaches to effectively transform the school system by encouraging collaboration among teachers to enhance quality teaching and learning practices (MOE, 2015). As many local researches on PLCs have already been conducted in government schools, this study was to examine the implementation of PLCs in the government-aided schools, i.e. the National-type Chinese Primary Schools (NCPSs) in the state of Perak, Malaysia. This was also to examine the diversity and complexity of PLCs in different cultural contexts so as to broaden our understanding of critical education issues in Malaysia. The study was to provide information that can align practices to address context specificity in enhancing PLCs practices in the implementation of the Blueprint.

\section{Professional learning Communities and its Contextual Factors}

The concept of PLCs was already in place three decades ago (Barth, 1990; Sizer, 1992). In the 1990s, the notion of PLCs gained tremendous attention in western educational settings especially in the USA. Basically, PLCS are viewed as trusting communities in which teachers engage in learning together by constructing knowledge and meaning collectively and collaboratively (DuFour \& Eaker 
1998; Hairon \& Dimmock, 2012; Hord, 1997; Zhang and Pang, 2016). It is perceived as the "best hope for school reform" especially in improving teaching quality and student learning (Harris, 2010; Hipp \& Huffman, 2010; Louis, 2008; Olivier \& Hipp, Qiao, Yu, Zhang, 2018; Pyhalto, Soini \& Pietarinena, 2011). Five common characteristics of PLCs were identified by American researchers (e.g. Dufour \& Eaker, 1998; Hord, 1997; Kruse, Louise and Bryk, 1995): shared norms and vision, collaboration, focus on student learning, de-privatization of practice and reflective dialogue. This conceptualization of PLCs has greatly influenced many of the PLC models, not only in Anglo American settings, but also in other cultural contexts.

PLC literature is quite rich in both theoretical and applied content. It is also evident that the practice of PLCs is found embedded in cultural and organizational contexts (Koffeman and Snoek, 2018; Lee \& Kim, 2016; Pang, Wang \& Leung, 2016; Vangrieken et al., 2017; Zhang \& Pang, 2016). In other words, PLCs developed variably with distinct cultural, social and institutional factors. Timperley (2008) emphasized that to effectively examine any implementation of PLCs, the context within which PLCs are located should be given attention as it is greatly influenced by societal factors in the community. In fact the above argument was congruent with Stoll, Bolam, McMahon, Wallace and Thomas (2006) who concluded that school location, student backgrounds, resource accessibility, school infrastructures, district policies and the attitude of the local community toward schooling are among those contextual factors that influence the effectiveness and sustainability of PLCs in schools.

While investigating the implementation of PLCs in Singapore schools, Hairon and Dimmock (2012) point out that the institutional and cultural settings in Singapore are very different from Western countries; the hierarchical education system in Singapore and its strong social culture characterized by strong central power and respect for authority are salient features that shape and impact the practices of PLCs in Singapore schools. In examining the practice of PLCs in Hong Kong, Pang et al (2016) also found that the organizational, societal and cultural factors were greatly influenced by the traditional Chinese collectivism and appeared to have significant impact upon the implementation of PLCs in the school communities.

In an effort to investigate the educational reforms and the implementation of PLCs in Shanghai and Mianyang, two Chinese cities located in the East and the Southwest of China respectively, Zhang and Pang (2016) concluded that school teachers in Mianyang had more PLC practices than those in Shanghai. Indeed, the significant differences in terms of economic, educational, social and cultural development in both these cities have had a profound impact upon PLC development in schools. As the PLC process becomes embedded within schools, the contextual factors within the organization or communities would determine, to a certain extent, how schools are able to re-culture and sustain highly effective PLCs (Olivier \& Huffman, 2016). The above PLC practices in Singapore, Hong Kong, Shanghai and Mianyang greatly support Wenger's (1998) theory of PLCs' context specificity.

\section{Contextual Background of the Study - The National-Type Chinese Primary Schools}

Primary schooling was made compulsory in 2003 in Malaysia so as to ensure that every child has access to primary education. There are three main types of primary schools in Malaysia: government schools, government-aided schools and private schools. Government schools are situated on public land and given the status of "government schools" or National Schools, which 
are fully under the Education Ministry's responsibility in terms of funding and maintenance. Those schools located on private donated land are accorded the status of "government-aided schools". Private schools (excluding international or expatriate schools) are those not funded or aided by the government. They operate independently based on their own resources.

Most of the NCPSs operate as government-aided schools. In comparison with government schools, the NCPSs receive less funding from the Ministry of Education (MOE), but the government is responsible for funding the school operations, teachers' training and salary, and setting the school curriculum (Ministry of Education Malaysia, 2013). However, funding in other areas such as the building of the school and utility expenses, are the responsibility of the local ethnic communities even though the NCPS is an integral part of the national educational system since 1957. It is also observed that the NCPSs are managed by boards of directors made up of strong supporters from the local Chinese community, who place a high priority in safeguarding and ensuring a conducive environment for study. Hence, fund-raising is their main strategy to gather funds for the school, with the Chinese community being a strong donor for this purpose (Raman \& Tan, 2015).

Primary education in Malaysia starts on the first day of the year when a child turns seven in that year and it is completed after six years. The NCPSs adopt the same national syllabus used by the government schools and offer the same school-leaving examination, the Primary School Achievement Test (Ujian Pencapaian Sekolah Rendah). The Malay language remains a compulsory subject in NCPSs whereas English is conducted as a third language (English is taught as a second language in government schools). The teaching of the Chinese language is compulsory in NCPSs and is the medium of instruction for all non-language subjects. In Malaysia, vernacular school education is protected under the 1996 Education Act. This is in line with the Constitution of multiracial Malaysia to preserve ethnic language and culture.

Government schools and the government-aided schools are open to all Malaysian children regardless of their race. However, government schools are largely populated by Malay children, with a small representation from the Indian children. As the NCPS are specifically designed for the Chinese children to learn their mother tongue as well as their culture, $90 \%$ of the students are Chinese. However, there have been an increasing number of non-Chinese children in NCPSs in the past ten years. This is perhaps due to NCPSs having stricter disciplinary and educational methods (Raman \& Tan, 2015). Notwithstanding the rise of China as an economic powerhouse may have also raised the awareness of the need for Mandarin learning globally.

\section{Methodology}

\section{Sample}

The study employed a quantitative approach by using the survey method. Multiple-staged stratified random procedure was applied in the study for selecting the number of NCPSs involved in the survey because of its highly recommended efficiency; each important segment is adequately represented and thus increased the likelihood of representation as well as the possibility of greater accuracy (Fraenkel \& Wallen, 2009). As shown in Table 1, there were altogether 10 districts in Perak with 185 NCPSs. The researcher decided to have a total of 25 percent of each stratum of the district, and as a result 46 NCPSs were selected randomly for the survey. Except the district of Perak Tengah, the number of NCPSs of each district engaged in the study ranged from two to nine. 
Next, to provide a better picture of the phenomenon examined, data were collected through the approach of triangulation, i.e. from the head teachers, senior assistants as well as the teachers. For every school, the head teacher was identified as the first respondent. Three senior assistants and fifteen teachers were also selected randomly as respondents. As shown in Table 1, for each school, there were 19 respondents involved in the study. In total, there were 46 head teachers $(46 \times 1), 138$ senior assistants $(46 \times 3)$ and 690 teachers $(46 \times 15)$ or, a total of 874 respondents were identified for the study.

Table 1. Total number of schools and respondents of each district of Perak engaged in the survey

\begin{tabular}{lcccc}
\hline $\begin{array}{c}\text { Districts of } \\
\text { Perak }\end{array}$ & $\begin{array}{c}\text { No. of schools } \\
\text { in each district }\end{array}$ & $\begin{array}{c}\text { No. of school } \\
\text { involved } \\
\text { in the survey }\end{array}$ & $\begin{array}{c}\text { No. of } \\
\text { respondents in } \\
\text { each school }\end{array}$ & $\begin{array}{c}\text { No. of } \\
\text { respondents in } \\
\text { each district }\end{array}$ \\
\hline Batang Padang & 23 & 6 & 19 & 114 \\
Manjung & 24 & 6 & 19 & 114 \\
Kinta Utara & 35 & 9 & 19 & 171 \\
Kinta Selatan & 22 & 5 & 19 & 95 \\
Krian & 10 & 2 & 19 & 38 \\
Kuala Kangsar & 16 & 4 & 19 & 76 \\
Hilir Perak & 20 & 5 & 19 & 95 \\
Larut & 23 & 6 & 19 & 114 \\
Hulu Perak & 11 & 3 & 19 & 57 \\
Perak Tengah & 1 & 0 & 0 & 0 \\
\hline
\end{tabular}

\section{Survey instrument}

PLCs were examined by using Professional Learning Communities Scale (PLCS) developed by Tai, Omar \& Ghouri (2018). The PLCS encompasses two main dimensions i.e. Organizational Factor and Non-organizational Factor. Organizational Factor consists of four sub-dimensions namely, Shared Norms and Vision, Head Teacher's Commitment and Support, Structural Support and Collegial Understanding and Trust. Shared Norms and Vision is the extent to which school members share visions pertaining to student learning, pedagogical purpose, and school improvement and effectiveness, and support norms of behaviours that guide decisions about the concerned purposes. Head Teacher's Commitment refers to the extent to which head teacher supports and is committed to the development and enhancement of PLCs in school and will take optimal steps to face any obstacles. Structural Support is viewed as the extent to which the administrative system, procedures and policies support the development and enhancement of PLCs in terms of time arrangement, space, facilities, resources and funding. Collegial Understanding and Trust is the extent to which school members develop mutual understanding and respect, trust, mindful and caring relationships that facilitate group processes to solve problems, make decisions and promote change (Tai et al., 2018).

Non-organizational Factor also encompasses four sub-dimensions namely, Collaborative Learning, Reflective Dialogue, Collective Inquiry and External Support System. Collaborative Learning is viewed as the extent to which the teacher practise collaborative learning that includes 
constantly sharing information, resources and works collaboratively to plan, solve problems, strengthen teaching practice and improve student learning. Reflective Dialogue refers to the maintenance of a dialogue journal or participation in reflective conversations in groups or pairs that might help the teacher gain new insights about teaching practices, and the perspectives are usually shared in an atmosphere of mutual support. Collective Inquiry means the extent to which school encourages the staff to build upon shared knowledge by examining systematically and collectively their educational practices and impact. External Support System is seen as the initiatives to improve outreach and collaboration with stakeholders including families, communities, district and state education departments, in the process of developing and promoting PLCs in schools (Tai et al., 2018).

The PLCS consists of 63 items and held convergent validity; the Squared Multiple Correlations (SMC) achieved the recommended threshold of 0.5. (Hair et al., 2010; Holmes-Smith, 2001), the Average Extracted Value (AVE) all surpassed the threshold of $50 \%$ (Fornell and Larker, 1981), and the Composite Reliability Index (CRI) achieved at least 0.70 (Hair et al., 2006). Besides, it also provides evidence for discriminant validity; the AVE of the factors achieved the recommended acceptance level of more than 0.50 (Hair et al., 2006; Kline, 2011) and the CRI was greater than 0.70 (Hair et al., 2006). The instrument was a six-point Likert-type scale and respondents were requested to rank their responses from "strongly disagree" to "strongly agree". The data interpretation for the level of PLCs is based on the measurement of two indicators i.e. frequency of the performance and performance rating as shown in Table 2.

Table 2. Raw Scores of PLCs and its level and indicators

\begin{tabular}{llll}
\hline Raw Scores & Level of PLCs & \multicolumn{2}{c}{ Indicators } \\
& & $\begin{array}{l}\text { Frequency of the } \\
\text { Performance }\end{array}$ & Performance Rating \\
\hline $5.51-6.00$ & Very good & Almost all of the time & Very satisfactory \\
$5.01-5.50$ & Good & Often & Satisfactory \\
$4.01-5.00$ & Quite good & Quite Often & Quite satisfactory \\
$3.01-4.00$ & Fair & Sometimes & Average \\
$2.01-3.00$ & Quite poor & Quite Rarely & Quite Dissatisfactory \\
$1.51-2.00$ & Poor & Rarely & Dissatisfactory \\
$1.00-1.50$ & Very poor & Almost Never & Very Dissatisfactory \\
\hline
\end{tabular}

\section{Data analysis}

The data collection process was taken over a time span of six weeks and adhered to all ethical considerations. Of 874 sets of questionnaires sent to 46 NCPSs, 662 sets were returned or with a response rate of $75.74 \%$. As there were 32 sets of questionnaires with illegible responses, only 630 sets of questionnaires were included for the final analysis. These included 41 sets from head teachers, 115 from senior assistants and 474 from teachers. The study employed a descriptive statistical analysis to obtain scores and means whereas the inferential statistical analysis such as the t-test was adopted to test the significance of the differences between or among the concerned variables based on the significance level of .05. 
INTERNATIONAL JOURNAL OF ACADEMIC RESEARCH IN PROGRESSIVE EDUCATION AND DEVELOPMENT

Vol. 8, No. 2, 2019, E-ISSN: 2226-6348@ 2019 HRMARS

\section{Demographic Characteristics}

Of the respondents involved in the survey, $80 \%(\underline{N}=504)$ were female and $20 \%(\underline{N}=126)$ were male. Among the respondents in the sample, the age group of 31 to 40 years consisted of $40.79 \%$ $(\underline{N}=257) ;$ the age group of 51 to 60 years $21.91 \%$ ( $\underline{N}=138) ; 41$ to 50 years $20 \%(\underline{N}=126)$ and the age group of 41 to 40 encompassed $17.30 \%$ ( $\underline{N}=109)$. Most of the respondents or $73.49 \%(\underline{N}=463)$ had a Diploma degree, followed by $21.75 \%$ respondents with a Bachelor's degree $(\underline{N}=137)$ and $4.76 \%$ $(\underline{\mathrm{N}}=30)$ had a Master's degree. In addition, more than one-fourth of the respondents or $25.24 \%$ $(\underline{N}=159)$ had worked more than five years, $24.29 \%$ ( $\underline{N}=153$ ) had worked more than 20 years, $22.38 \%$ $(\underline{N}=141) 11$ to 15 years, 17.77\% ( $\underline{N}=112) 6$ to 10 years and $10.32 \%$ ( $\underline{N}=65)$ had worked 16 to 20 years.

\section{Findings}

As shown in Figure 1, the mean score for PLCs, Organizational Factor and Non-organizational Factor of PLCs were 4.79, 4.90 and 4.68, respectively. Based on the raw scores and the level of PLCs displayed in Table 2, this indicated that the NCPSs achieved the level of Quite Good in PLCs as well as its dimensions i.e. the Organizational Factor and Non-organizational Factor as the mean scores fell within 4.01 to 5.00. Further, as shown in Figure 2, the NCPSs also achieved the level of Quite Good across all the eight sub-dimensions of PLCs as the mean scores ranged from 4.47 to 4.96.

Comparing the Organizational Factor and Non-organizational Factor of PLCs, the Organization Factor $(M=4.90)$ of the NCPSs achieved a higher mean score than the NonOrganizational Factor ( $\mathrm{M}=4.68)$; a difference of .22 was observed between the two factors. Importantly, the difference was significant, $t=250.265, \mathrm{df}=629, \mathrm{p}<.05$ (Table 3).

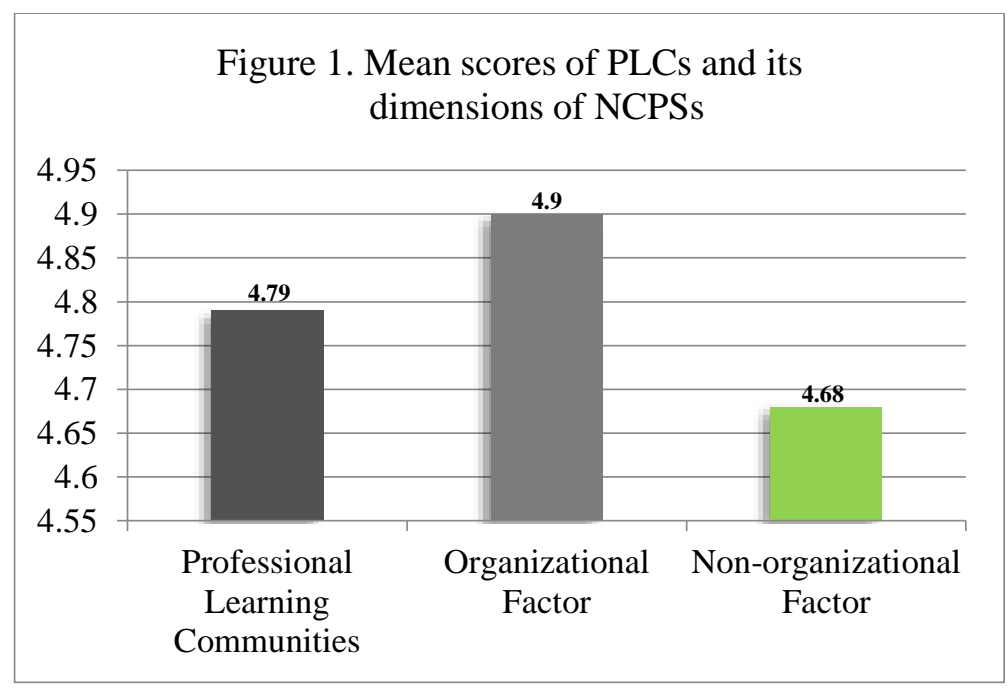


INTERNATIONAL JOURNAL OF ACADEMIC RESEARCH IN PROGRESSIVE EDUCATION AND DEVELOPMENT

Vol. 8, No. 2, 2019, E-ISSN: 2226-6348 @ 2019 HRMARS

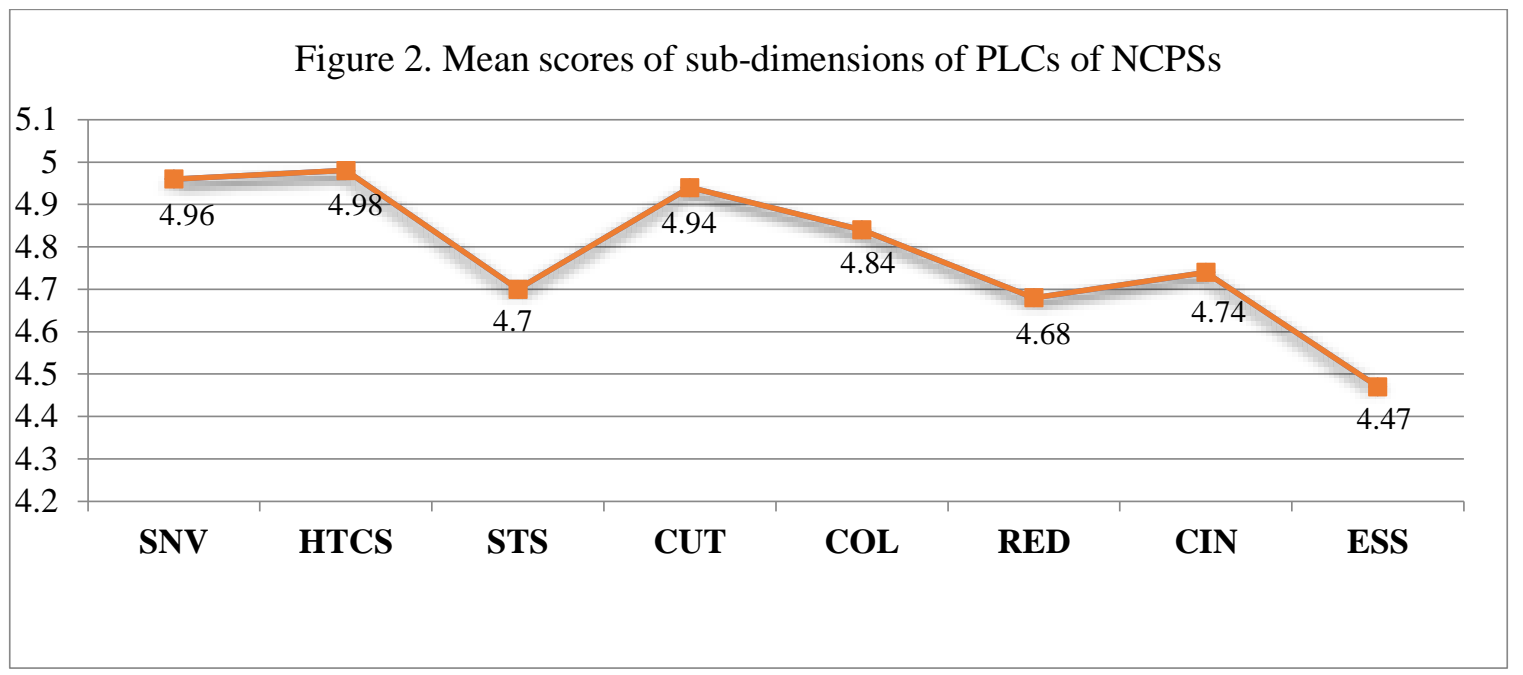

Note. SNV= Shared Norms and Vision; HTCS= Head Teacher's Commitment \& Support; STS=Structural

Support; CUT= Colleague Understanding \& Trust; COL= Collaboration; RED=Reflective Dialogue; $\mathrm{CIN}=$ Collective Inquiry; ESS= External Support System

Table 3. One sample t- test for organizational factor and non-organizational factor

\begin{tabular}{|c|c|c|c|c|c|c|}
\hline & \multirow[b]{2}{*}{$\mathrm{t}$} & \multirow[b]{2}{*}{$d f$} & \multirow[b]{2}{*}{ Sig. (2-tailed) } & \multirow{2}{*}{$\begin{array}{c}\text { Mean } \\
\text { Difference }\end{array}$} & \multicolumn{2}{|c|}{$\begin{array}{c}95 \% \text { Confidence Interval of } \\
\text { the Difference }\end{array}$} \\
\hline & & & & & Lower & Upper \\
\hline OF & 250.265 & 629 & .000 & 4.89549 & 4.8571 & 4.9339 \\
\hline NOF & 230.993 & 629 & .000 & 4.68221 & 4.6424 & 4.7220 \\
\hline
\end{tabular}

Besides, in terms of all the eight sub-dimensions of PLCs (Figure 2), the NCPSs achieved the highest mean score in Head Teacher's Commitment and Support ( $M=4.98)$. A close examination by all the eight items of Head Teacher's Commitment and Support (Table 4), the seventh item, 'My head teacher always provide teachers with emotional support when they face problems in student learning' achieved the highest mean score $(M=5.09)$. This was followed by the third item, 'My head teacher provides constructive feedback for teachers through constant class observation' ( $M=5.04)$. These three items: the first, second and the fifth item, 'My head teacher uses every possible means to help teachers to teach at their best '; 'My head teacher devotes sufficient time to settle potential problems pertaining to student learning'; and 'My head teacher provides opportunities for communication across departments in enhancing student learning' achieved a mean score of five, respectively. The sixth item, 'My head teacher always create opportunities to engage teachers in decision making about student learning' ( $M=4.98)$; the fourth item, 'My head teacher often create opportunities for teachers to share best practices about effective teaching' $(M=4.96)$ and the 
INTERNATIONAL JOURNAL OF ACADEMIC RESEARCH IN PROGRESSIVE EDUCATION AND DEVELOPMENT

Vol. 8, No. 2, 2019, E-ISSN: 2226-6348 @ 2019 HRMARS

eighth item, 'My head teacher gives recognition to those teachers who strive toward the realization of effective teaching' ( $M=4.78)$ were those three items that achieved a mean score of less than five.

Table 4. Mean scores for items of Head Teacher's Commitment and Support

\begin{tabular}{|c|c|c|}
\hline No. & Item & Mean \\
\hline & $\begin{array}{l}\text { My head teacher uses every possible means to help teachers to teach at their } \\
\text { best }\end{array}$ & 5.00 \\
\hline & $\begin{array}{l}\text { My head teacher devotes sufficient time to settle potential problems pertaining } \\
\text { to student learning }\end{array}$ & 5.00 \\
\hline & $\begin{array}{l}\text { My head teacher provides constructive feedback for teachers through constant } \\
\text { class observation }\end{array}$ & 5.04 \\
\hline & $\begin{array}{l}\text { My head teacher often create opportunities for teachers to share best practices } \\
\text { about effective teaching }\end{array}$ & 4.96 \\
\hline & $\begin{array}{l}\text { My head teacher provides opportunities for communication across departments } \\
\text { in enhancing student learning }\end{array}$ & 5.00 \\
\hline & $\begin{array}{l}\text { My head teacher always create opportunities to engage teachers in decision } \\
\text { making about student learning }\end{array}$ & 4.98 \\
\hline & $\begin{array}{l}\text { My head teacher always provide teachers with emotional support when they } \\
\text { face problems in student learning }\end{array}$ & 5.09 \\
\hline & $\begin{array}{l}\text { My head teacher gives recognition to those teachers who strive toward the } \\
\text { realization of effective teaching }\end{array}$ & 4.78 \\
\hline
\end{tabular}

On the other hand, among all the eight sub-dimensions of PLCs, as shown in Figure 2, the NCPSs achieved the lowest mean score in External Support System (M=4.47). While examining closely all the eight items of External Support System, as depicted in Table 5, the second item, 'The parent-teacher association involves actively in promoting shared responsibility for student learning' ( $M=4.36)$ achieved the lowest mean score. This was followed by the fifth item, 'The local communities provide multiple opportunities for collaboration in enhancing student learning' $(\mathrm{M}=4.40)$; the fourth item, 'The local communities provide financial support /resources for the improvement of school facilities' $(M=4.41)$; and the eighth item, 'District /State education department provides high quality professional development programmes for teachers' (M=4.49). The third item, 'The old boy/girl association acts actively as a source of assistance in continuous school improvement' ( $M=4.50)$; the sixth item, 'Partnerships between schools help teachers to share solutions to commonly faced problems in teaching practice' ( $M=4.52)$; the first item, 'Parents are willing to cooperate with the school to take effective initiative for intentional student improvement' $(\mathrm{M}=4.53)$ and the seventh item, 'Sustained communication about student learning is available between school management and the stakeholders' ( $M=4.58)$ were the four items that achieved a mean score of 4.50 or above. 
INTERNATIONAL JOURNAL OF ACADEMIC RESEARCH IN PROGRESSIVE EDUCATION AND DEVELOPMENT

Vol. 8, No. 2, 2019, E-ISSN: 2226-6348 @ 2019 HRMARS

Table 5. Mean scores for items of External Support System

\begin{tabular}{|c|c|c|}
\hline No. & Item & Mean \\
\hline & $\begin{array}{l}\text { Parents are willing to cooperate with the school to take effective initiative for } \\
\text { intentional student improvement }\end{array}$ & 4.53 \\
\hline 2. & $\begin{array}{l}\text { The parent-teacher association involves actively in promoting shared responsibility } \\
\text { for student learning }\end{array}$ & 4.36 \\
\hline 3. & $\begin{array}{l}\text { The old boy/girl association acts actively as a source of assistance in continuous } \\
\text { school improvement }\end{array}$ & 4.50 \\
\hline 4. & $\begin{array}{l}\text { The local communities provide financial support /resources for the improvement of } \\
\text { school facilities }\end{array}$ & 4.41 \\
\hline 5. & $\begin{array}{l}\text { The local communities provide multiple opportunities for collaboration in enhancing } \\
\text { student learning }\end{array}$ & 4.40 \\
\hline 6. & $\begin{array}{l}\text { Partnerships between schools help teachers to share solutions to commonly faced } \\
\text { problems in teaching practice }\end{array}$ & 4.52 \\
\hline & $\begin{array}{l}\text { Sustained communication about student learning is available between school } \\
\text { management and the stakeholders }\end{array}$ & 4.58 \\
\hline & $\begin{array}{l}\text { District /State education department provides high quality professional } \\
\text { development programs for teachers }\end{array}$ & 4.49 \\
\hline
\end{tabular}

\section{Discussion}

Several meaningful observations emerged from the study. Firstly, the NCPSs achieved the level of Quite Good in PLCs, in its two dimensions i.e. the Organizational Factor and Non-organizational Factor as well as in all its eight sub-dimensions. Based on the interpretation of the level of PLCs suggested in Table 2, this implied that the teachers of NCPSs who practised PLCs 'quite often' also had 'quite satisfied' performance. If PLCs are viewed as the "best hope for school reform" especially in improving student learning (Hipp \& Huffman, 2010; Hord \& Sommers, 2008; Olivier \& Hipp, 2016), then it would imply that there is a need for teachers of NCPSs to 'often' practice PLCs with 'satisfied' performance to be effective in conducting quality and powerful student learning. Therefore, it can be argued then that there is room for improvement for the teachers of the NCPSs in Perak in practising PLCs.

As mentioned earlier, the MOE started to implement PLCs in the schools in 2011, and developing a peer-led culture of PLCs is one of the important approaches to achieve the objectives of the Malaysia Education Blueprint 2013-2025 (MOE, 2015). On the one hand, the MOE has emphasised the professional development of school leaders to enhance their capacity in developing and supporting PLCs in schools; on the other, the MOE has also conducted training programmes concurrently for teachers to promote authentic learning through collaborative interaction, open sharing of classroom management, deep reflection of teaching practices, and exchange of feedback to enhance teachers' capability to effectively implement and sustain PLCs in the school communities. Thus in this way, the MOE provides school leaders and teachers with different programmes so as to expand relevant competencies in the development of effective PLCs in schools. 
INTERNATIONAL JOURNAL OF ACADEMIC RESEARCH IN PROGRESSIVE EDUCATION AND DEVELOPMENT

Vol. 8, No. 2, 2019, E-ISSN: 2226-6348 @ 2019 HRMARS

The NCPSs only achieved the level of Quite Good in PLC; this result could be linked to the lack of effective professional development programmes pertaining to PLCs offered by the MOE. This ineffectiveness could also infer the lack of quality of professional development activities (Darling-Hammond, Hyler \& Gardner, 2017), inexperienced trainers (Chapman, 2005), the disconnection between theory and practice (Mitgang, 2012), the relevancy of the programmes attended by the teachers (Tai \& Omar, 2018) or whether it is job-embedded (Poekert, 2012), the lack of follow-up support (Kea, Carse \& Jess, 2019; Kuipers, Houtveen \& van de Grift, 2019), and the incidence or frequency of being exposed to the training programmes (Mitgang, 2012; Singh, 2009) by the school leaders and teachers. As a result, there is a lack of technical know-how and confidence in engaging the teachers in developing effective PLCs in NCPSs.

On closer examination, there is evidence that the above shortcomings are closely related to the second finding --- the NCPSs in Perak achieved a lower mean score in Non-Organizational Factor than Organizational Factor and the difference was significant; the Non-Organizational Factor was the dominant factor in comparison with the Organizational Factor in contributing to the level of Quite Good in practising PLCs in NCPSs. Succinctly, at the non-organizational level --- the extent of how teacher perform PLCs in terms of Collaborative Learning, Reflective Dialogue and Collective Inquiry and how various stakeholders and the local community support PLCs through External Support System were less encouraging than the organizational factor --- the extent of how the school leaders develop and support the practice of PLCs in terms of Shared Norms and Vision, Head Teacher's Commitment and Support, Structural Support and Collegial Understanding and Trust in NCPS.

In the light of the above, it appears that the professional development programmes conducted by the MOE to develop and sustain effective PLCs in schools are basically sufficient and relevant for school leaders as compared to the schoolteachers. Indeed, ensuring a high-quality head teacher in every school is one of the important shifts of the Blueprint to drive overall school performance in transforming the education system (Ministry of Education 2016). Therefore, despite of the normal professional development programmes for school leaders such as the National Professional Qualification for Educational Leaders (NPQEL) conducted by Institut Aminuddin Baki, the training arm of MOE for school leaders, head teachers are also provided with different programmes to equip them with subsequent competencies to lead change in schools, which includes training programmes for developing PLCS (MOE, 2018).

Since the head teachers have been exposed to such extensive training, they would be expected to initiate, develop and sustain PLCs in schools. These efforts include sharing goals with the staff about student learning, pedagogical purpose and support norms of behaviours that guide decisions about the concerned purposes (Shared Norms and Vision); support and commit to the development and enhancement of PLCs in schools and to take optimal means and steps to solve problems pertaining to the implementation and sustainability of PLCs (Head Teacher's Commitment and Support); implement procedures and policies that support and facilitate the implementation of PLCs, specifically in terms of time arrangement, facilities, space, resources and funding (Structural Support); promote mutual understanding and respect, trust and develop good rapport that facilitate group processes to make decisions, solve problems and lead change in the schools effectively (Collegial Understanding and Trust). 
INTERNATIONAL JOURNAL OF ACADEMIC RESEARCH IN PROGRESSIVE EDUCATION AND DEVELOPMENT

Vol. 8, No. 2, 2019, E-ISSN: 2226-6348 @ 2019 HRMARS

The result that the NCPSs of Perak achieved a lower mean score in Non-Organizational Factor than Organizational Factor can probably be explained from another perspective. While examining the important roles of school leaders and teachers in developing and supporting PLCs in schools, Huffman and Jacobson (2003), Hipp and Huffman (2010) highlight that there is always a tendency that as due attention has been given to the importance of school leadership in promoting and supporting PLCs, the role of the teachers in supporting PLCs tends to be neglected. To a large extent, this issue may be linked significantly to whether teacher leadership that serves as the key tenet of PLCs (Hairon, 2016; Hargreaves and Elhawary, 2019; Roudledge, 2018; Harris et al., 2018), has been given much emphasis and attention. Although the importance of conversations in teacher learning communities has been spelt out among Malaysian schools (MOE, 2015), this did not warrant for such leadership sustaining conversations in the teacher learning community to be emphasised or established in the NCPSs.

The practice of teacher leadership not being given sufficient attention might be one of the reasons why the NCPSs of Perak achieved a lower mean score in Non-Organizational Factor than Organizational Factor. Teachers learn to work and take on leadership roles to lead learning, foster deep collaboration, transform teacher learning environments, change classroom practice and improve student learning. They exhibit leadership values that create effective instructional practices and credibility; they would be in the best position to make informed decisions about instructional strategies, designing lessons and providing academic support. Therefore, if the practice of teacher leadership is not given sufficient attention, the extent of how teacher perform PLCs in terms of Collaborative Learning, Reflective Dialogue and Collective Inquiry and how various stakeholders and the local community support PLCs through External Support System in NCPS would be jeopardized.

Indeed, the conditions that foster teacher leadership are those that cultivate and support teacher professional learning that are central to the development of leadership abilities among the teachers at different levels. Research literature identifies a significant number of contributing factors including a strong foundation of trust that contributes to a 'virtuous cycle' of leadership development (Smylie et al., 2007), a sense of autonomy to initiate changes and a feeling that teachers' ideas are respected or heard (Beachum \& Dentith, 2004), role clarity, physical structures and organizational structures (Galland, 2008), open lines of communication (Ackerman \& Mackenzie, 2006), and shared professional practice, recognition and reward (Muijs \& Harris, 2006). King (2016) also reminds us that the importance of systemic factors in the school environment including support from professional peers may contribute to the above phenomenon. Thus, further research to examine the abovementioned factors is crucial to ascertain the effectiveness of the practice of teacher leadership in NCPSs as it is at the forefront of PLCs implementation and sustainability (Routledge, 2018).

Another potential reason why the NCPSs in Perak achieved a lower mean score in NonOrganizational Factor than Organizational Factor might be the tensions experienced by teachers when participating or promoting PLCs in school communities. PLC is a complex form of learning that involves the engagement of the teachers collectively and collaboratively, which can cause feelings of tension. Tensions are seen as anxiety, stress or loss of self-efficacy caused by conflicting workplace affordances and personal features of teachers, and can slow down the pace of promoting PLCs in school communities (Billett, 2009; Vangrieken et al., 2017; Schaap et al. 2018). 
INTERNATIONAL JOURNAL OF ACADEMIC RESEARCH IN PROGRESSIVE EDUCATION AND DEVELOPMENT

Vol. 8, No. 2, 2019, E-ISSN: 2226-6348 @ 2019 HRMARS

Workplace affordances are cultural (e.g. beliefs, values and ideas), structural (e.g. power, roles, relationship) or material (workplace environment, resources) conditions and the extent to which they are available or flexible; personal features are the characteristics of the teachers that can impact the way they regulate their workplace affordances, such as their needs, motives and expectations for their own professional development as well as for school improvement (Schaap et al., 2018). The failure of getting the alignment between these two factors can cause tensions that could affect the learning processes of NCPSs teachers.

For example, in the process of promoting PLCs, teachers need time and space for Collaborative Learning, Reflective Dialogue, Collective Inquiry and get cooperation from External Support System. However, if they are always experiencing emotionally intensive situations due to being highly involved with the development and learning of the students, heavy interactions with colleagues, parents or any other stakeholders, these could be the cause of feelings of tension with the teachers. Tensions also arise when teachers experience a lack of resources in enhancing student learning; discrepancy between actual and required knowledge in implementing PLCs especially in connecting the PLCs with school development; conservative learning culture such as individually oriented learning culture in school community; and lack of involvement, interest or investment from other colleagues in promoting PLCs. To this end, more research is needed to identify the complex interactions among the contextual factors and their impact on PLCs, and to explicitly investigate the resulting tensions in the context of PLCs in NCPSs.

Another workplace affordance as indicated by the achieved lower mean score of NonOrganizational Factor might be the teachers' heavy workload. Research reviews demonstrate that school-based PLCs can be impeded by the working conditions of the teachers (Hairon and Dimmock, 2012; Kim and Ju, 2012; Lee, 2011; Seo, 2011; Zhang and Pang, 2016). Kim and Ju (2012) found that excessive administrative work was a reason why teachers were reluctant to pay much attention to teaching and learning. In the same vein, Zhang and Pang (2016) pointed out that teachers from Mianyang of China who have lesser workloads had taken a great deal of initiative to establish PLCs as compared to those in Shanghai who have heavy workloads. In fact, as learning is a mutual construct between two or more people, an effective learning relationship needs time to initiate interactive dialogue. Time is an additional impediment to teacher capacity in taking on extra work (Muijs \& Harris, 2006). In Malaysia, teachers are generally preoccupied with administrative paperwork (Juliana \& Arumugam, 2016). The NCPSs teachers being involved directly or indirectly in fund raising for the schools; this demand on their time could perhaps add to their workload as well. This seems to be another inference from the substantial amount of variation in their engagement in Collaborative Learning, Reflective Dialogue, Collective Inquiry or External Support System.

Thirdly, in terms of all the eight sub-dimensions of PLCs, the NCPSs achieved the highest mean score in Head Teacher's Commitment and Support. The result implied that the commitment and support of the head teachers for developing PLCs in NCPSs were more sufficient and relevant in comparison with other sub-dimensions. Substantial research on PLCs has emphasized the importance of school leaders in transforming schools as learning organizations within the learning system. For example, Cordingley (2015), Khalid and Strange (2016), Vangrieken et al. (2017) highlighted that the school leaders play a critical supportive role in fostering and sustaining PLCs. If school leaders practise relational leadership that is vision-driven rather than position-driven, or 
INTERNATIONAL JOURNAL OF ACADEMIC RESEARCH IN PROGRESSIVE EDUCATION AND DEVELOPMENT

Vol. 8, No. 2, 2019, E-ISSN: 2226-6348 @ 2019 HRMARS

a collaborative role instead of a supervisory role, it would foster a positive evaluation of teachers toward the efforts taken and this in turn would encourage the teachers to engage in developing and sustaining PLCs in schools.

A close examination of all the eight items of Head Teacher's Commitment and Support (Table 4) found that the head teachers of NCPSs were working sensitively with teachers and served as emotional anchors to help teachers cope with negative emotions; the seventh item, 'My head teacher always provide teachers with emotional support when they face problems in student learning' achieved the highest mean score $(M=5.09)$. Indeed, school change is associated with emotional and interpretative conflicts. As mentioned earlier, the failure of getting the alignment between workplace affordances and personal features of teachers can easily create conflicts and negative emotions. However, if the head teachers are able to help the teachers in practising interpersonal emotion management, they will be able to regulate teachers' emotions and initiate a positive perspective that contributes to teacher performance in the process of creating, developing and sustaining effective PLCs.

There seems to be a positive and supportive role of the head teachers of NCPS in helping teachers to improve and enhance their instructional activities: the third item, 'My head teacher provides constructive feedback for teachers through constant class observation' $(M=5.04)$; the first item, 'My head teacher uses every possible means to help teachers to teach at their best' $(M=5.00)$; the second item, 'My head teacher devotes sufficient time to settle potential problems pertaining to student learning' $(M=5.00)$; the fifth item, 'My head teacher provides opportunities for communication across departments in enhancing student learning' ( $M=5.00)$; and the fourth item, 'My head teacher often create opportunities for teachers to share best practices about effective teaching' ( $M=4.96)$. These were the items with the mean scores between 4.96 and 5.04. To a large extent, such commitment will enhance the capacity of the teachers to maintain and sustain PLCs. Strong PLCs are likely to emerge with a high level of commitment from the head teachers of NCPSs.

The head teachers of NCPSS also value the voice of the teachers in decision-making: the sixth item, 'My head teacher always create opportunities to engage teachers in decision making about student learning' ( $M=4.98$ ). According to Bauman (2015), building mutualistic relationship is a way to seek common ground for the school organization on both the macro and micro levels. This is a form of social influence that goes beyond individuals and implies collective agency (Ogawa \& Bossert, 1995) that is essential for the sustainability of PLCs. In addition, the eighth item, 'My head teacher gives recognition to those teachers who strive toward the realization of effective teaching' $(M=4.78)$ shows that the head teachers recognize the struggles the teachers experienced and the efforts of the teachers in developing successful PLCs. In summary, if teachers believe their head teachers are valuing their ideas and recognizing their work, their intrinsic motivational levels certainly will be increased and this will benefit the developing and the sustainability of the PLCs in schools overall.

On the other hand, among all the eight sub-dimensions of PLCs, the NCPSs achieved the lowest mean score in External Support System. This implied that the initiatives taken by NCPSs to improve outreach and collaboration with stakeholders including families, communities, district and state education departments in the process of developing and promoting PLCs, were less sufficient and relevant in comparison with other sub-dimensions. In fact, there are more complex and diverse contexts in education that demands teachers to communicate and collaborate with a wider range 
of stakeholders, within and across schools and communities. Hence, the development and enhancement of school-based PLCs depends not only on the internal structures and processes, but on external influencing factors and stakeholders as well (Osmond-Johnsona et al., 2019; Spencer 2016). Therefore, to promote, sustain and extend PLCs effectively, schools appear to need external support, networking and other partnerships (Sperandio and Kong, 2018).

For instance, recent research has demonstrated that inviting the community into the school can effectively communicate the importance of PLCs and build sustainability and support from all stakeholders (Spencer, 2016); the importance of funding, providing professional support and guidance from district officers in the realization of powerful PLCs in schools (Cowan et al., 2012; Olivier \& Huffman, 2016; Osmond-Johnsona et al., 2019; Thessin \& Starr, 2011), and the importance of the relationship between teacher organizations and other educational stakeholders in the area of teacher professional learning (Osmond-Johnsona et al., 2019). In short, the involvement of various stakeholders and the local community allow teachers and stakeholders to work together in fostering the development of PLCs within schools that impact teaching practices positively and ultimately improve student learning.

Looking closer at all the eight items of External Support System (Table 5), it is clear that there is room for improvement for the collaboration between NCPSs in Perak and various stakeholders to promote PLCs. On this note, the partnership with the parent-teacher associations is crucial as the second item, 'The parent-teacher association involves actively in promoting shared responsibility for student learning' achieved the lowest mean score. Indeed the genuine dialogue and cooperation between teachers and parents are central to the improvement of student learning as they are the individuals closest to the students. The NCPSs also need support from the local communities (the fourth item) and the old boys/girls association (the third item) specifically in providing financial support or resources for the improvement of school facilities, as this funding is not under the responsibility of the MOE. Without enough funding, it is difficult to have sufficient facilities that facilitate teachers' learning in the process of developing effective PLCS in NCPSs.

In terms of teacher professional development, the NCPSs need the support from the district or state education department (the eighth item) to provide high quality professional development programmes for the teachers in enhancing instructional activities. These cover the school-based CPD programmes and effective professional development programmes from the district or state education department that allow teachers to learn new knowledge, skills and strategies for teaching and to make changes in the classrooms. In addition, the NCPSs also realize that partnerships between schools (the sixth item), the willingness of parents to cooperate with the school (the first item) and the collaboration between school management and the stakeholders (the seventh item) are not sufficient and yet these are important steps for developing effective PLCs that will enhance student learning.

\section{Conclusion}

PLCs have been increasingly promoted and implemented by school systems as one strategy for teacher capacity building and sustaining school change that impact student achievement. The study has painted a picture of how PLCs are being implemented in NCPSs in Perak, Malaysia and broadens our understanding of the situation. The results have revealed that the NCPSs in Perak need to improve their implementation of PLCs if it is to be effective in addressing school reforms. 
The study has provided the basis for further research in four broad emphasis areas: i) the effectiveness of professional development programmes pertaining to PLCs for school leaders and teachers of NCPSs; ii) the practice of teacher leadership that serves as the key tenet of PLCs in the NCPSs that is traditionally based upon a top-down and linear leadership style instead of a bottomup approach; iii) the complex interactions between the workplace affordances and personal features of teachers that give rise to feelings of tension in implementing PLCs in NCPSs; and iv) how to improve and enhance the implementation and the sustainability of PLCs through External Support System in NCPSs. Practically, if PLCs offer the promise of better teaching and learning, it will be necessary for educators and educational leaders to rethink and revise some current practices or even policies so that they serve desired educational goals in improving PLCs in NCPSs. The study also offers educational researchers a more comprehensive analysis in exploring PLCs towards a continuous and sustained school improvement, specifically in comparison with other types of primary schools in Malaysia. This added perspective would certainly move the PLCs literature to a level that is based on proven theory yet is practically doable for engagement.

\section{Acknowledgements}

This work was supported by the LLG Cultural Development Centre Berhad, Malaysia (Code: 20190045-106-29).

\section{References}

Ackerman, R. H., \& Mackenzie, S. V. (2006). Uncovering teacher leadership. Educational Leadership, 6(8), 66-71.

Barth, R. S. (1990). Improving schools from within: teachers, parents and principals can make the difference. San Francisco: Jossey-Bass.

Bauman, C. (2015). A refreshing perspective on teacher leadership: How teacher leaders effectively combine the use of autonomy and collaboration to enhance school improvement. Leading and Managing, 21(2), 46-59.

Beachum, F., \& Dentith, A. M. (2004). Teacher leaders creating cultures of school renewal and transformation. The Educational Forum, 68(3), 276-286, doi:10.1080/00131720 40898 4639

Billett, S. (2009). Conceptualizing learning experiences: Contributions and mediations of the social, personal and brute. Mind, Culture and Activity, 16, 32-47. Doi:

10.1080/10749030802477317

Chapman, J. D. (2005). Recruitment, retention, and development of school principals (Education Policy Series). Paris: UNESCO.

Cordingley, P. (2015). The contribution of research to teachers' professional learning and development. Oxford Review of Education, 41 (2), 234-252.

doi:10.1080/03054985.2015.1020105

Cowan, D., Joyner, S., \& Beckwith, S. (2012). Getting serious about the system: A field book for district and school leaders. Thousand Oaks, CA: Corwin Press.

Darling-Hammond, L., Hyler, M.E., \& Gardner, M. (2017). Effective teacher professional development. Palo Alto, CA: Learning Policy Institute

Desimone, L. M. (2009). Improving impact studies of teachers' professional development: 
INTERNATIONAL JOURNAL OF ACADEMIC RESEARCH IN PROGRESSIVE EDUCATION AND DEVELOPMENT

Vol. 8, No. 2, 2019, E-ISSN: 2226-6348 @ 2019 HRMARS

Toward better conceptualizations and measures. Educational Researcher, 38(3), 181-199.

DuFour, R., \& Eaker, R. (1998). Professional learning communities at work: Best practices for enhancing student achievement. Bloomington, IN: National Education Service.

Fornell, C., \& Larcker, D. (1981). Structural equation models with unobservable variables and measurement error: Algebra and statistics. Journal of Marketing Research, 18(August), 382388.

Fraenkel, J. R., \& Wallen, N. E. (2009). How to design and evaluate research in education (3 ed.). New York, NY: McGraw-Hill.

Galland, C. (2008). Effective teacher leadership: A quantitative study of the relationships between school structures and effective teacher leaders. Unpublished Doctoral Thesis, University of Missouri, Columbia.

Hair, J. F., Black, W. C., Babin, B. J., \& Anderson, R. E. (2010). Multivariate data analysis: A global perspective. New Jersey: Pearson Prentice Hall.

Hairon, S. (2016). Facilitation for professional learning community conversations in Singapore. Asia Pacific Journal of Education, 36(2), 285-300, doi:10.1080/02188791.2016.1148855

Hairon, S., \& Dimmock, C. (2012). Singapore schools and professional learning communities: Teacher professional development and school leadership in an Asian hierarchical system. Educational Review, 64(4), 405-424.

Hargreaves, E., \& Elhawary, D. (2019). Professional development through mutually respectful relationship: senior teachers' learning against the backdrop of hierarchical relationships', Professional Development in Education, 45(1), 46-58. doi: org/10.1080/19415257. 2018.1500390

Harris, A. (2010). Leading system transformation. School Leadership and Management, 30(30), 197-207.

Harris, A., Jones, M., \& Huffman, J. B. (2018). Teachers leading educational reform: The power of professional learning communities. London, UK: Routledge.

Hipp, K. K., \& Huffman, J. B. (2010). Demystifying the concept of professional learning communities. In K. K. Hipp \& J. B. Huffman (Eds.), Demystifying professional learning communities: School leadership at its best (pp. 11-22). New York, NY: Rowman \& Littlefield Education.

Holmes-Smith, P. (2001). Introduction to Structural Equation Modelling using LISREAL. Perth: ACSPRI-Winter Training Program.

Hord, S. (1997). Professional learning communities: Communities of continuous inquiry and improvement. Austin, TX: Southwest Educational Development Laboratory (SEDL).

Hord, S. M., \& Sommers, W. A. (2008). Leading professional learning communities: Voices from research and practice. Thousand Oaks: Corwin Press.

Huffman, J. B., \& Jacobson, A. L. (2003). Perceptions of professional learning Communities', International Journal of Leadership in Education, 6(3), 239-250. doi: org/10.1080/1360312022000017480

Institut Aminuddin Baki. (2018). Training programmes 2018. Genting Highlands: Institut Aminuddin Baki, Ministry of Education Malaysia.

Jensen, B. (2012). Catching up: Learning from the best school systems in East Asia. Sydney: 
INTERNATIONAL JOURNAL OF ACADEMIC RESEARCH IN PROGRESSIVE EDUCATION AND DEVELOPMENT

Vol. 8, No. 2, 2019, E-ISSN: $2226-6348$ @ 2019 HRMARS

Grattan Institute.

Juliana, M., \& Arumugam, M. (2016, September 19). Ministry to cut teachers' workload, stop resignations. Retrieved from https://www.malaymail.com/news/malaysia/ 2016/09/19/ministry-to-cut-teachers-workload-stop-resignations/1208717

Keay, J. K., Carse, N., \& \& Jess, M. (2019). Understanding teachers as complex professional learners. Professional Development in Education, 45(1), 125-137.

Khalid, M.S., \& Strange, M.H. (2016). School teacher professional development in online communities of practice: A systematic literature review. In: J. Novontá and A. Janaík, eds. Proceedings of the 15th European conference one-learning, Vol. 1. 1. Reading, UK: Academic Conferences and Publishing International, 605-614.

Kim, H., \& Ju, Y. (2012). The significance and challenges of distributed leadership practice for building school-based professional learning community. The Journal of Research in Education, 43, 1-26.

King, F. (2016). Teacher professional development to support teacher professional learning: Systemic factors from Irish case studies. In: teacher development. 20(4), 574-594. doi:10.1080/13664530.2016.1161661

Kline, R. B. (2011). Principles and practice of Structural Equation Modelling (3 ${ }^{\text {rd }}$ ed.). New York, NY: Guilford.

Koffeman, A., \& Snoek, M. (2018). Identifying context factors as a source for teacher professional learning. Professional Development in Education. Advance online publication. doi: 10.1080/19415257.2018.1557239

Kruse, S. D., Louis, K. S., \& Bryk, A. S. (1995). An emerging framework for analysing school based professional community. In K. S. Louis \& S. D. Kruse (Eds.), Professionalism and community: Perspectives on reforming urban schools (pp. 23-42). Thousand Oaks, CA: Corwin

Kuijpers, J. M., Houtveen, A.A.M., \& van de Grift, W.J.C.M. (2019). Effects of professional support in school improvement. Educational Studies, 45(10), 113-130. doi: 10.1080/03055698.2018.1443798

Lee, K. (2011). The study on the roles of principal in professional learning community. The Journal of Educational Administration, 29(3), 95-221.

Lee, M., \& Kim, J. (2016). The emerging landscape of school-based professional learning communities in South Korean schools. Asia Pacific Journal of Education, 36(2), 266-284.

Louis, K. S. (2008). Creating and sustaining professional communities. In A. M. Blankstein, P. D. Houston, \& R. W. Cole (Eds.), Sustaining professional learning communities (pp. 41-57). Thousand Oaks, CA: Corwin Press.

Ministry of Education Malaysia. (2013). Malaysia Education Blueprint 2013-2025. Putrajaya: Ministry of Education Malaysia.

Ministry of Education Malaysia. (2015). Malaysia education blueprint 2013-2025: 2015 annual Report. Putrajaya: ministry of education malaysia.

Ministry of Education Malaysia. (2016). Malaysia education blueprint 2013-2025: 2016 annual report. Putrajaya: ministry of education malaysia.

Mitgang, L. (2012). The making of the principal: Five lessons in leadership training. New York, NY: The Wallace Foundation. 
INTERNATIONAL JOURNAL OF ACADEMIC RESEARCH IN PROGRESSIVE EDUCATION AND DEVELOPMENT

Vol. 8, No. 2, 2019, E-ISSN: 2226-6348 @ 2019 HRMARS

Muijs, D., \& Harris, A. (2006). Teacher led school improvement: Teacher leadership in the UK. Teaching \& Teacher Education: An International Journal of Research and Studies, 22(8), 961972.

Ogawa, R. T., \& Bossert, S. T. (1995). Leadership as an organizational quality. Educational Administration Quarterly, 31(2), 224-243.

Olivier, D. F., \& Hipp, J. B. (2016). Professional learning community process in the United States: Conceptualization of the process and district support for schools. Asia Pacific Journal of Education, 36(2), 301-317.

Olivier, D. F., \& Huffman, J. B. (2016). Professional learning community process in the United States: Conceptualization of the process and district support for schools. Asia Pacific Journal of Education, 36(2), 301-317.

Osmond-Johnson, P., Campbell, C., \& Faubert, B. (2019). Supporting professional learning: the work of Canadian teachers' organizations. Professional Development in Education, 45(1), 17-32. doi: 10.1080/19415257.2018.1486877

Pang, N. S., Wang, T., \& Leung, L. (2016). Educational reforms and the practices of professional learning community in Hong Kong primary schools. Asia Pacific Journal of Education, 36(2), 231-247. doi: 10.1080/02188791.2016.1148852

Poekert, P. E. (2012). Teacher leadership and professional development: Examining links between two concepts central to school improvement. Professional Development in Education, 38(2), 169-188. doi: 10.1080/19415257.2012.657824

Pyhalto, K., Soini, T., \& Pietarinena, J. (2011). A systemic perspective on school reform: Principals' and chief education officers' perspectives on school development. Journal of Educational Administration, 49(1), 46-61.

Qiao, X., Yu, S., \& Zhang, L. (2018). A review of research on professional learning communities in mainland China (2006-2015): Key findings emerging themes. Educational Management Administration and Leadership, 46(5), 713-728. doi: 10.1177/1741143217707523

Raman, S. R., \& Tan, Y. S. (2015). The development of Chinese education in Malaysia: Problems and challenges. The ISEAS working paper series, ISEAS-Yusof Ishak Institute.

Roudledge, (2018). Teachers leading educational reform (Publisher's description of book) Retrieved from http://www. Routledge.com/Teachers-Leading-Educational-Reform-The Power-of-Professional -Learning/Harris-Jones-Huffman/p/book/9781138641068

Schaap, H., Louws, M., Meirink, J., Oolbekkink-Marchand, H., Van Der Want, A., Zuiker, I., Meijer, P. (2018). Tensions experienced by teachers when participating in a professional learning community. Professional Development in Education. Advance online publication. doi: 10.1080/19415257.2018.1547781

Seo, K. (2011). Collaborative professional development of online teacher community. The Journal of Korean Teacher Education, 28(1), 133-161.

Singh, G. S. B. (2009). The National Professional Qualification for Headship (NPQH) Programme for Secondary School Head Teachers in Malaysia: An Evaluative Case Study. Unpublished Doctoral Thesis, University of Birmingham

Sizer, T. R. (1992). Horace's school: Redesigning the American high school. Boston: Houghton Mifflin.

Spencer, E. J. (2016). Professional Learning Communities: Keeping the Focus on 
INTERNATIONAL JOURNAL OF ACADEMIC RESEARCH IN PROGRESSIVE EDUCATION AND DEVELOPMENT

Vol. 8, No. 2, 2019, E-ISSN: 2226-6348 C 2019 HRMARS

Instructional Practice. Kappa Delta Pi Record, 52 (2), 83-85, doi:10.1080/00228958.2016.1156544

Sperandio, J., \& Kong, P. A. (2018). Forging professional learning communities: The role of external agency. International Journal of Leadership in Education, 21(1), 80-94, doi: 10.1080/13603124.2016.1182646

Stoll, L., Bolam, R., McMahon, A., Wallace, M., \& Thomas, S. (2006). Professional learning communities: A review of the literature. Journal of Educational change, 7(4), 221-258.

Tai, M. K., \& Omar, A. K. (2018). Headteacher change leadership competency: A study in Malaysian primary schools. Professional Development in Education. Advance online publication. doi: 10.1080/19415257.2018.1561494

Tai, M. K., \& Omar, A. K. (2019). Professional learning communities: A comparison study between Day Secondary School and Fully Residential Secondary School in Malaysia, International Journal of Academic Research in Progressive Education and Development, 8(2), 87-101.

Tai, M.K., Omar, A.K., \& Ghouri, A.M. (2018). Developing a preliminary model on professional learning community in Malaysian secondary school (Unpublished research report which was funded by Fundamental Research Grant Scheme [Code: 2017-0196-10701], Ministry of Higher Education Malaysia). Sultan Idris Education University, Perak Darul Ridzuan, Malaysia.

Thessin, R. A., \& Starr, J. P. (2011). Supporting the growth of effective professional learning communities district wide. Phi Delta Kappan, 92, 48-54.

Timperley, H. (2008). Teacher professional learning and development. Educational Practices Series-18, International Bureau of Education, UNESCO.

Vangrieken, K., Meredith, C., Packer, T., \& Kyndt, E. (2017). Teacher communities as a context for professional development: a systemic review. Teaching and Teacher Education, 61, 4759. doi: org/10.1016/j.tate.2016.10.001

Wang, T. (2015). Contrived collegiality versus genuine collegiality: Demystifying professional learning communities in Chinese schools. Compare, 45(6), 908-930.

Wenger, E. (1998) Communities of practice: Learning, meaning, and identity. Cambridge. UK; New York: Cambridge University Press.

Zhang, J., \& Pang, N.S.K. (2016). Investigating the development of professional learning communities: Compare schools in Shanghai and Southwest China. Asia Pacific Journal of Education, 36(2), 217-230. 